\title{
Purification and characterization of an extracellular peptide factor that affects two different developmental pathways in Bacillus subtilis
}

\author{
Jonathan M. Solomon, Beth A. Lazazzera, and Alan D. Grossman ${ }^{1}$ \\ Department of Biology, Massachusetts Institute of Technology, Cambridge, Massachusetts 02139 USA
}

\begin{abstract}
We have purified and characterized an extracellular peptide factor that serves as a cell density signal for both competence development and sporulation in Bacillus subtilis. This competence and sporulation stimulating factor (CSF) was purified from conditioned medium (culture supernatant) based on its ability to stimulate expression of $\operatorname{srf} A(\mathrm{comS})$ in cells at low cell density. CSF is a 5-amino-acid peptide, glu-arg-gly-met-thr (ERGMT), that is, the carboxy-terminal 5 amino acids of the 40 -amino-acid peptide encoded by phrC. No detectable CSF was produced in a phrC null mutant. The activity of chemically synthesized CSF (ERGMT) was virtually indistinguishable from that of CSF that was purified from culture supernatants. At relatively low concentrations (1-10 nM), CSF stimulated expression of $\operatorname{srf} A$, whereas high concentrations of CSF stimulated the ability of cells at low cell density to sporulate. Stimulation of $\operatorname{srfA}$ expression by CSF requires the oligopeptide permease encoded by $\operatorname{spo} 0 \mathrm{~K}$, a member of the ATP-binding-cassette family of transporters, and the putative phosphatase encoded by $\operatorname{rap} C$, the gene immediately upstream of phrC. RapC was found to be a negative regulator of $\operatorname{srf} A$ expression, suggesting that the target of RapC is the transcription factor encoded by $\operatorname{comA}$. We propose that CSF is transported into the cell by the Spo0K oligopeptide permease and stimulates competence gene expression by inhibiting (either directly or indirectly) the RapC phosphatase.
\end{abstract}

[Key Words: Genetic competence; sporulation; phosphatase; kinase; cell-cell signaling]

Received June 4, 1996; revised version accepted July 8, 1996.

Cell-cell signaling is utilized by many types of cells to regulate gene expression and development. One form of cell-cell signaling involves a regulatory response to cell density signals. This process, sometimes called quorum sensing (Fuqua et al. 1994), is typically characterized by regulatory events that are induced as cells grow to high cell density. A variety of chemicals, including acyl homoserine lactones, peptides, and amino acids, are used for microbial cell-cell signaling (Kaiser and Losick 1993) to regulate many biological processes, including genetic exchange, development, virulence, bioluminescence, and production of antibiotics.

In the Gram-positive bacterium Bacillus subtilis, the development of genetic competence is regulated by cell density signals (Magnuson et al. 1994; Solomon et al. 1995). B. subtilis, like many species of bacteria, has the natural ability to become competent for the uptake of exogenous DNA (Spizizen 1958; for review, see Solomon and Grossman 1996). Early regulatory steps in competence development occur in response to two peptide factors that accumulate in culture medium as cells grow to

${ }^{1}$ Corresponding author. high density. One factor, the ComX pheromone, is a 9- or 10-amino-acid peptide with a modified tryptophan residue (Magnuson et al. 1994). The second factor, competence and sporulation stimulating factor $(\mathrm{CSF})$, was found previously to be a peptide between 520 and 720 daltons (Solomon et al. 1995). In this report, we describe the purification of CSF to homogeneity, and the biochemical and genetic characterization of this competence and sporulation stimulating factor.

Two convergent pathways control response to the two competence factors (Solomon et al. 1995). The histidine protein kinase encoded by $\operatorname{com} P$ (Weinrauch et al. 1990) is required for the response to the ComX pheromone (Solomon et al. 1995). The oligopeptide permease-encoded by spoOK (Perego et al. 1991; Rudner et al. 1991) is required for the response to the second competence factor, CSF (Solomon et al. 1995). Response to both competence pheromones contributes to the activation of the ComA transcription factor, a response regulator that is phosphorylated on an aspartate in the amino-terminal regulatory domain. Com $A \sim P$, in turn, activates transcription of $\operatorname{srfA}(\mathrm{com} S)$, which is required for competence development (Nakano and Zuber 1989; van Sinderen et al. 1990; Hahn and Dubnau 1991; Nakano and 
Zuber 1991; Nakano et al. 1991a,b; Roggiani and Dubnau 1993). High levels of expression of coms, a small open reading frame internal to the large $\operatorname{srf} A$ operon (D'Souza et al. 1994; Hamoen et al. 1995), contribute to activation of the ComK transcription factor and expression of the late com genes that encode the DNA uptake machinery (Hahn et al. 1994; van Sinderen and Venema 1994; van Sinderen et al. 1994, 1995).

We have found that CSF is a 5 -amino-acid peptide that stimulates expression of $\operatorname{srf} A$ when added to cells at low cell density. A synthetic peptide of the same sequence glu-arg-gly-met-thr (ERGMT) as the peptide purified from culture supernatants was biologically active, with peak activity for $\operatorname{srf} A$ expression in the concentration range of $2-5 \mathrm{~nm}$. CSF is encoded by the last 5 codons of a 40 codon open reading frame that was identified initially as being downstream from a promoter recognized by RNA polymerase containing sigma-H (Carter et al. 1991). This open reading frame, named $p h r C$ (Perego et al. 1996), is preceded by a gene $(\operatorname{rap} C)$ that encodes a product that is homologous to, and probably is, a response regulator aspartyl phosphate phosphatase (Perego et al. 1996). Our results indicate that the RapC phosphatase is a negative regulator of srf $A$ expression and competence, probably by inhibiting accumulation of ComA P, and that RapC is required for CSF to stimulate competence gene expression.

Under conditions of nutrient deprivation, cells of $B$. subtilis can initiate a developmental pathway that leads to the formation of dormant heat-resistant spores (Errington 1993). Like competence development, efficient sporulation requires a relatively high cell density (Vasantha and Freese 1979; Grossman and Losick 1988; Waldburger et al. 1993). Experiments characterizing the cell density signals for sporulation indicated that one extracellular sporulation factor was copurifying with CSF, but that much more of the active fraction was needed to affect sporulation than to affect competence. Experiments with chemically synthesized CSF demonstrate that the pentapeptide can stimulate sporulation of nutrient-deprived cells at low cell density, indicating that CSF is both a competence and sporulation stimulating factor.

\section{Results}

\section{Purification of CSF}

Expression of $s r f A$ increases as cells grow to high density in minimal medium because of the extracellular accumulation of two different peptide factors, ComX pheromone and CSF (Magnuson et al. 1994; Solomon et al. 1995; Solomon and Grossman 1996). When added to cells at low cell density, ComX pheromone and CSF cause $\beta$-galactosidase-specific activity from a $\operatorname{srf} A-l a c Z$ fusion to increase approximately 10 -fold and 3 -fold, respectively, $70 \mathrm{~min}$ after addition of the factor (Magnuson et al. 1994; Solomon et al. 1995). CSF was separated from ComX pheromone and purified to homogeneity from cell-free conditioned medium (culture supernatant) made from cells grown to high density (see Materials and methods|. The ability to stimulate expression of a srfAlacZ fusion in cells at low cell density was used as an assay to follow CSF activity through the purification (see Materials and methods). Typically, twofold serial dilutions of column fractions were assayed because CSF was active in a relatively small concentration range and too much seemed to inhibit expression of $s r f A-l a c Z$ (see below).

Material from conditioned medium was adsorbed first to $\mathrm{C} 18$ reverse phase columns, washed to remove all media components, and CSF activity was eluted with $11 \%$ acetonitrile. Active material was then fractionated on a series of FPLC and HPLC columns (see Materials and methods). The elution profile from the final reverse phase column is shown in Figure 1. There is a single peak of material that has CSF activity, assayed by the ability to induce expression of $\operatorname{srf} A-l a c Z$ in cells at low cell density. This peak of CSF activity corresponds to a peak of absorbance at $218 \mathrm{~nm}$ (indicative of peptide bonds). This peak had no detectable absorbance at $280 \mathrm{~nm}$, indicating the absence of aromatic amino acids.

Mass spectrometry of the purified material indicated that CSF was 609 daltons (data not shown). Edman degradation and fragmentation mass spectrometry revealed the presence of a five-amino-acid peptide, N-glu-arg-glymet-thr-C (ERGMT). This sequence is consistent with the previous finding that CSF activity is sensitive to treatment with trypsin (Solomon et al. 1995). The predicted mass of this peptide is 593 daltons 16 daltons less than the mass of the purified material. However, it was apparent from the fragmentation mass spectrometry of the purified material that the methionine residue was oxidized (to a sulfoxide), accounting for the 16 dalton discrepancy. This oxidation probably occurred during the purification and did not detectably affect CSF activity. Reduction of the purified material yielded a mass peak of 593 daltons as expected (data not shown).

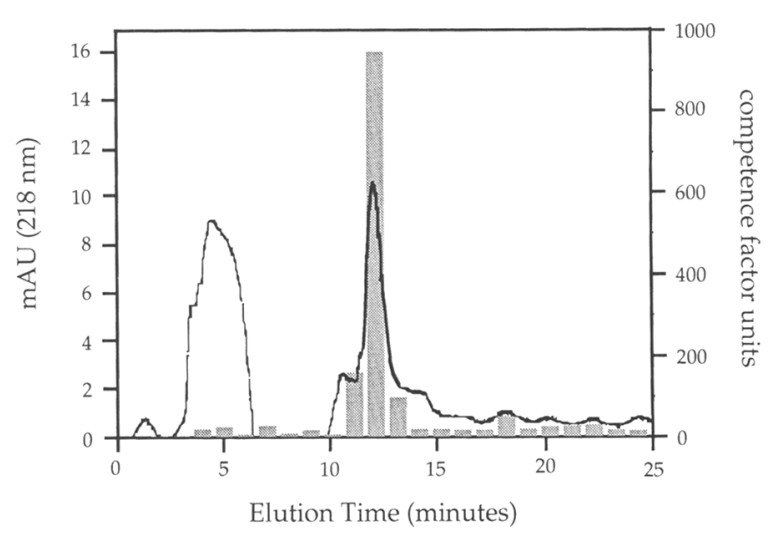

Figure 1. CSF activity and C18 reverse phase HPLC column profile. Absorbance at $218 \mathrm{~nm}$ of the material eluting from the final $\mathrm{C} 18$ reverse phase column is plotted versus elution time. The bars represent units of CSF activity in the fractions, measured as the ability to induce expression of $s r f A-l a c Z$ in cells at low cell density (see Materials and methods). 


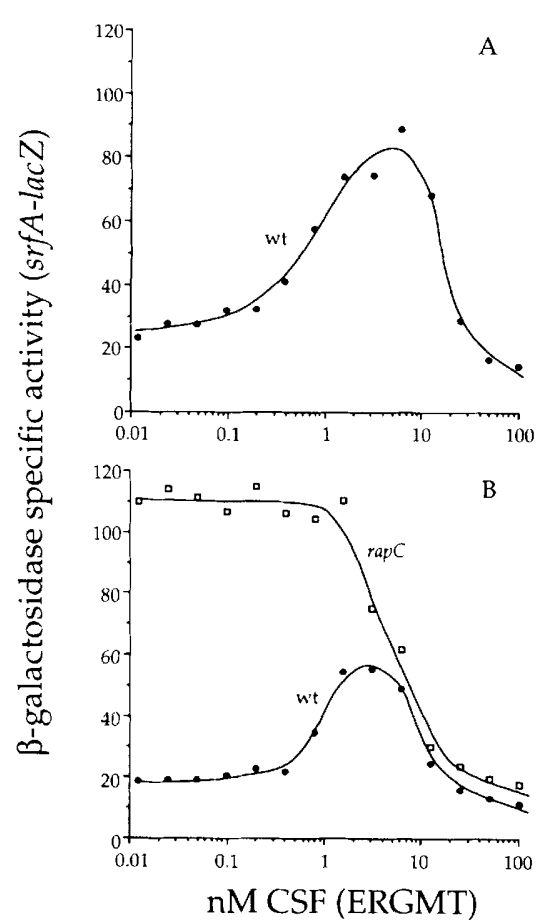

Figure 2. Expression of $\operatorname{srf} A-l a c Z$ in response to chemically synthesized peptide (ERGMT) in the wild-type and rap $C$ mutant. Cells were grown in minimal medium, and at low cell density cells were mixed with indicated amounts of ERGMT, incubated for $70 \mathrm{~min}$ at $37^{\circ} \mathrm{C}$ and $\beta$-galactosidase specific activity was assayed. (A) Dose response of wild-type cells (JRL293) to CSF. The $\beta$-galactosidase specific activity of cells with no added peptide was 23. (B) Dose response of wild-type (JRL476) (O) and the rapC mutant (BAL116) ( $\square$ ) to CSF. The $\beta$-galactosidase-specific activity of cells with no added peptide was 20 for wild-type and 108 for the rapC mutant. The initial level of $s r f-l a c Z$ at low cell density in the rap $C$ mutant is higher than that in wild type, but there was no further induction upon addition of various amounts of CSF. The rapC mutant is able to respond to the ComX pheromone (data not shown).

\section{Synthetic ERGMT has biological activity of CSF}

We determined that a chemically synthesized peptide (ERGMT) had the same biological activity as CSF purified from culture supernatants. Addition of the synthetic peptide to cells at low cell density induced expression of srfA-lac $Z$ approximately 3 -fold (Fig. 2A), comparable to CSF that was purified from conditioned medium (Solomon et al. 1995). The synthetic peptide was most active in the concentration range from $\sim 2$ to $5 \mathrm{~nm}$. High concentrations (greater than $50 \mathrm{nM}$ ) actually inhibited expression of srfA-lacZ (Fig. 2A), similar to previous findings with partly purified CSF (R. Magnuson, J.M. Solomon, and A.D. Grossman, unpubl.). The mechanism of this inhibition is not yet understood, but might have to do with the activation of regulatory pathways affecting sporulation (see below).

CSF is encoded by phrC, a gene downstream from a promoter controlled by sigma-H

The CSF pentapeptide matches exactly the carboxy-ter- minal five amino acids of a 40-amino-acid open reading frame (Fig. 3). This 40-amino-acid ORF was identified initially because it is immediately downstream from a promoter controlled by the $\mathrm{spoOH}$ gene product, sigma-H (Carter et al. 1991). This is consistent with the previous finding that CSF production is greatly reduced in a spoOH null mutant (Solomon et al. 1995). The 40-aminoacid ORF has been named $p h r C$ recently (Perego et al. 1996), because of the assumption that it encodes a phosphatase regulator. $\mathrm{phrC}$ is immediately downstream from $r a p C$, whose gene product is homologous to a response regulator aspartyl phosphate phosphatase (Perego et al. 1996). DNA sequence of part of this region has been published (Carter et al. 1991) and the complete amino acid sequence of the rap $C$ gene product was reported in a review recently (Perego et al. 1996).

To determine if $p h r C$ was the only source of active CSF in culture supernatant, we constructed a $p h r C$ null mutant and tested conditioned medium from the mutant for CSF activity. A deletion-insertion of $p h r C$, $\Delta p h r C:: e r m$, was made using clones generated by PCR based on the published DNA sequence (see Materials and methods). Conditioned medium from the phrC null mutant was fractionated to distinguish CSF from ComX pheromone, as described previously (Solomon et al.

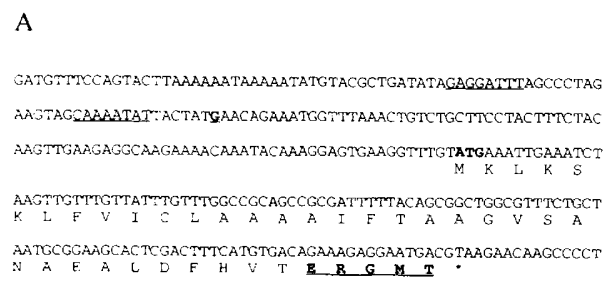

B

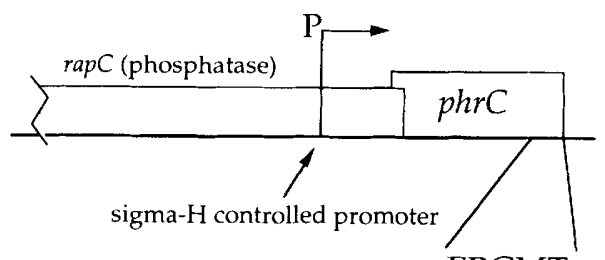

ERGMT

Figure 3. DNA sequence and map of the $p h r C$ region. $\{A \mid$ DNA sequence and predicted amino acid sequence of $p h r C$. DNA sequence is from published work (Carter et al. 1991). The DNA was originally characterized because of the promoter that is recognized and transcribed by RNA polymerase containing sigma-H (Carter et al. 1991). The DNA sequence of the putative -10 and -35 recognition sites are underlined and the start site of transcription is in bold and underlined. The start codon for $p h r C$ is in bold and the predicted phrC peptide is indicated. The carboxy-terminal 5 amino acids (ERGMT) are indicated in bold and underlined. These correspond to the CSF. $(B)$ Schematic of the rapC phrC region. $p h r C$ is downstream and overlaps rapC, which encodes a protein homologous to response regulator aspartyl phosphate phosphatases (Carter et al. 1991; Perego et al. $1996)$. 
1995), and fractions were tested for induction of srfAlac $Z$ in cells at low cell density. The $p h r C$ null mutant produced no detectable CSF activity (data not shown), indicating that $p h r C$ is required for CSF production and that $p h r C$ is the only expressed gene encoding CSF.

The phrC null mutation had modest effects on competence gene expression. The onset of $\operatorname{srf} A$ expression was delayed approximately one half of one generation and reached a maximal level of $\sim 60 \%$ of that in wildtype cells (Fig. 4A). The phrC null mutation also caused a delay and a slight reduction in expression of the late competence gene $\operatorname{com} G$, as measured by expression of a comG-lacZ fusion (Fig. 4B). This effect on expression of com $G-l a c Z$ was a reflection of a similar effect on competence development per se, as measured directly by determining transformation efficiency. The efficiency of transformation in the $p h r C$ null mutant was $\sim 50 \%$ of that in wild type. This small change in transformation efficiency is difficult to measure and the effect of the phrC mutation on competence is much more reliably seen by measuring the effect on com $G-1 a c Z$ expression. The decrease in $\operatorname{com} G$ expression (and competence) is probably attributable to the decrease in expression of $\operatorname{srf} A$, as $\operatorname{srf} A$ is required for expression of the late competence genes (for review, see Grossman 1995).

Previously, we found that $s p o O H$ null mutants had decreased expression of srfA (Jaacks et al. 1989), attribut-

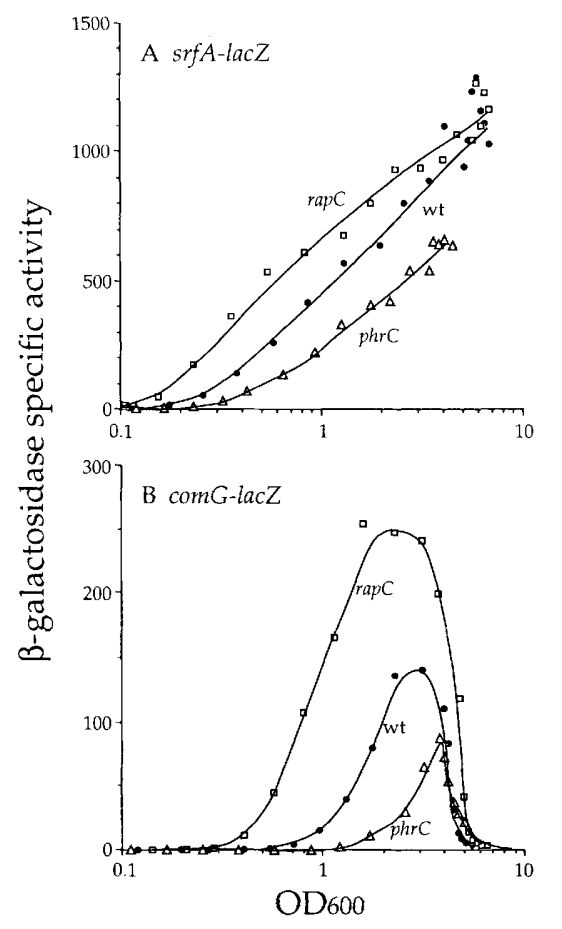

Figure 4. Effect of $p h r C$ and $\operatorname{rap} C$ null mutations on expression of $\operatorname{srf} A$ and $\operatorname{com} G$. Strains containing the $\operatorname{srf} A-l a c Z$ or $\operatorname{com} G$ $l a c Z$ fusion were grown in defined minimal medium and samples were taken at the indicated cell densities for determination of $\beta$-galactosidase specific activity. (A) Wild type, JRL476 (O); rapC, BAL116 ( $\square)$; phrC, JMS753 ( $\triangle) .(B)$ Wild type, JMS107 (O); rapC, BAL114 ( $\square)$; phrC, IMS752 $(\triangle)$. able to, at least in part, a decrease in production of CSF (Solomon et al. 1995). Interestingly, the defect in expression of $\operatorname{sr} A$ caused by a null mutation in $s p o O H$ is more severe than that caused by a null mutation in $p h r C$. This could be because of slightly reduced production of the ComX pheromone $(\sim 60 \%$ of normal) in a $5 p o 0 H$ mutant (Solomon et al. 1995), or could reflect an additional (indirect) role for sigma-H (spoOH) in expression of srfA.

Transcription from the sigma-H promoter that drives expression of $p h r C$ is known to increase as cells enter stationary phase, under the growth conditions tested (Carter et al. 1991), suggesting that the amount of CSF might also increase early in stationary phase. Preliminary experiments measuring the amount of CSF in culture medium from wild-type cells at different stages of growth indicate that production of CSF increases upon entry into stationary phase (B.A. Lazazzera and A.D. Grossman, unpubl.).

\section{CSF and ComX pheromone are the only major extracellular competence factors}

CSF is one of two extracellular factors that affect srfA expression (Magnuson et al. 1994; Solomon et al. 1995). Production of the ComX pheromone requires $\operatorname{com} X$, which encodes a 55-amino-acid precursor of the peptide moiety of the pheromone, and $\operatorname{com} Q$, the gene immediately upstream of (and overlapping with) $\operatorname{comX}$. Expression of $\operatorname{sr} A$ in the absence of the ComX pheromone (in a comQ null mutant) is reduced to $\sim 10 \%$ of that in wildtype cells (Magnuson et al. 1994; Solomon et al. 1995). Despite the strong dependence of $\operatorname{srf} A$ expression on the ComX pheromone, there is still a significant level of expression. We found that CSF is responsible for the bulk of the residual expression of $\operatorname{srf} A$ in the absence of the ComX pheromone. Expression of $\operatorname{srf} A$ in the absence of both ComX pheromone and CSF, in a comQ phrC double mutant, was $<20 \%$ of that in a comQ single mutant (Fig. 5 ). In addition, conditioned medium from the phrC com $Q$ double mutant had no detectable competence factor activity. That is, it was unable to induce $\operatorname{srf} A-l a c Z$ expression significantly above background in cells at low cell density (data not shown). These results indicate that ComX pheromone and CSF are the only extracellular competence factors that contribute significantly to expression of $s r f$.

Taken together, results with the $p h r C$ (missing CSF) and comQ (missing ComX pheromone) single and double mutants indicate that the ComX pheromone is the major competence pheromone that affects expression of $\operatorname{sif} A$, and that CSF modulates the timing and levels of $\operatorname{srf} A$ induction (Fig. 4). We suspect that physiological conditions alter production of each competence pheromone, and that different ratios of the two extracellular factors might cause different regulatory responses as cells grow to high density and enter stationary phase.

The RapC phosphatase is a negative regulator of srfA expression and competence

The rapC gene product is a member of a growing family 


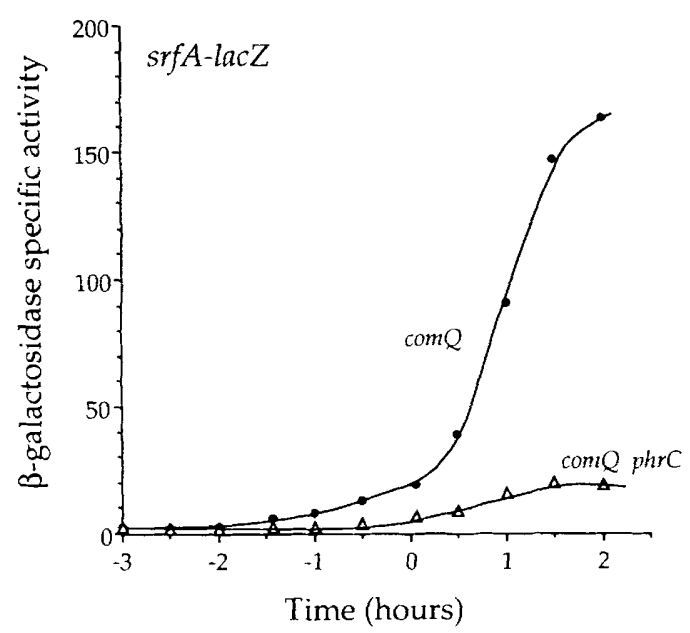

Figure 5. CSF is required for most of the residual expression of srf $A$ in the absence of ComX pheromone. The comQ null mutant produces no detectable ComX pheromone (Magnuson et al. 1994!, and was used because the com $X$ null mutation is polar on the downstream gene, com $P$ (histidine protein kinase). Strains containing the srf $A-l a c Z$ fusion were grown in minimal medium and $\beta$-galactosidase-specific activity was measured at the indicated times. Time zero $(0)$ is the time cells cease exponential growth. comQ, JMS761 (O); comQ phrC, JMS762 ( $\triangle$ ). $\beta$-galactosidase specific activity is presented as a function of time during the growth cycle (rather than as a function of optical density as in Fig. 4) because most of the significant expression of srfA occurs after the exponential phase of growth when there is little or no increase in optical density.

of response regulator aspartyl phosphate phosphatases (Perego et al. 1996). We examined the phenotype caused by a $\operatorname{rap} C$ mutation and found that $\mathrm{RapC}$ is a negative regulator of srfA expression. A null mutation in rapC (see Materials and methods) caused expression of both srfA-lacZ (Fig. 4A) and comG-lacZ (Fig. 4B) to be earlier and higher than that in wild-type cells. In addition, the transformation efficiency of the $\operatorname{rap} C$ mutant was $\sim 2-$ 3 -fold higher than that of wild-type cells. Because the phosphorylated form of the ComA response regulator is required for expression of srf $A$ and the subsequent development of competence (for review, see Dubnau 1991; Grossman 1995), these results indicate that the RapC phosphatase is probably a phophatase for the ComA transcription factor. The increase in $\operatorname{sif} A$ expression in the rapC null mutant is most likely attributable to increased accumulation of $\mathrm{ComA} \sim \mathrm{P}$, whereas the increase in competence and com $G$ expression is probably attributable to the increase in $\operatorname{srfA}$ expression.

\section{CSF stimulation of srfA expression requires the RapC phosphatase}

To determine if the RapC phosphatase is required for the response to CSF in vivo, we measured the ability of the rapC null mutant to respond to various amounts of the chemically synthesized CSF. Expression of srfA-lacZ is higher in the rapC mutant and this is especially notice- able at low cell densities (Figs. 2B, 4A). We found that there was little or no increase in expression of $\operatorname{srf} A-l a c Z$ in rapC mutant cells at low cell density in response to CSF (Fig. 2B). Expression of srfA-lacZ in wild-type cells at low density is typically induced $\sim 3$-fold upon addition of CSF (Fig. 2A,B). Together, these results indicate that RapC negatively regulates expression of $\operatorname{srf} A$ and that CSF antagonizes this negative regulation.

Interestingly, in the rap $C$ mutant, high concentrations of CSF inhibit expression of $\operatorname{srfA}$, similar to the inhibition in wild-type cells (Fig. 2B). This indicates that the inhibition does not depend on RapC and that CSF is affecting other regulatory factors in the cell.

\section{The oligopeptide permease encoded by spo0K can import CSF}

The oligopeptide permease encoded by spoOK is required for competence development (Rudner et al. 1991) and for the response to CSF (Solomon et al. 1995). We found that the SpoOK oligopeptide permease is able to transport the chemically synthesized CSF into the cell. We tested the ability of spoOK ${ }^{+}$and $s p o O K^{-}$cells to utilize the synthetic peptide ERGMT as a source of methionine to satisfy a methionine auxotrophy. The $s p o O K^{+}\left(\mathrm{met}^{-}\right)$cells were able to utilize ERGMT as a source of methionine while the $\operatorname{spoOK}\left(\mathrm{met}^{-}\right)$null mutant was not, as judged by the ability to grow on solid minimal medium with a drop of concentrated peptide. Whereas these results do not prove that the low amounts of CSF are actually imported to stimulate $\operatorname{sif} A$ expression, they do show that the SpoOK oligopeptide permease can import CSF. It seems likely that one role of the oligopeptide permease in competence development is to transport CSF into the cell where CSF then inhibits, either directly or indirectly, production or activity of the RapC phosphatase.

CSF enhances sporulation of nutrient-deprived cells at low cell density

The initiation of sporulation is also controlled, in part, by cell density signals (Grossman and Losick 1988; Ireton et al. 1993). In the course of characterizing the multiple peptide factors in conditioned medium that contribute to the cell density effect on sporulation, it became apparent that one extracellular sporulation factor was copurifying with CSF (data not shown). Chemically synthesized CSF was able to stimulate the sporulation frequency of nutrient-deprived cells at low cell density. That is, CSF has the activity of an extracellular sporulation factor.

Addition of high concentrations of CSF $(\geqslant 1 \mu M)$ seemed to stimulate sporulation of nutrient-deprived cells at low cell density. This stimulation (2-50-fold) was variable and seemed to depend very much on the initial cell density (data not shown). To more reproducibly detect possible effects of CSF on sporulation, we tried mixing CSF with conditioned medium from a spoOA mutant before addition to wild-type cells at low cell density. spoOA null mutants are defective in produc- 
tion of several extracellular products, including CSF (Solomon et al. 1995) and at least one major sporulation factor (Grossman and Losick 1988). When added to cells at low cell density, the combination of CSF $(50-100 \mathrm{nM})$ and spoOA-conditioned medium reliably and reproducibly stimulated sporulation $\sim 5-10$-fold (Fig. 6). Additional experiments indicated that increasing the amount of CSF (as high as $10 \mu \mathrm{M}$ ) did not inhibit sporulation (data not shown). Addition of either 50-100 nM CSF or conditioned medium from a spoOA null mutant alone usually had little, if any, effect on the ability of nutrient-deprived cells at low cell density to sporulate. Preliminary experiments indicate that the amount of CSF in culture medium (defined minimal medium) from wild-type cells grown to early stationary phase is probably $\geqslant 100 \mathrm{nM}$ (B.A. Lazazzera and A.D. Grossman, unpubl.), in the range in which sporulation is stimulated by CSF.

The phrC null mutant makes no detectable CSF, but also had no obvious effect on sporulation (data not shown). This is not surprising given that there are multiple peptide factors in conditioned medium that contribute to the cell density effect on sporulation. The effects of the $p h r C$ mutation on $\operatorname{srf} A$ and $\operatorname{com} G$ expression are modest; there is a delay and reduction of $-40 \%$ in the peak level of expression. If the phrC mutation had a comparable effect on sporulation, we would not have

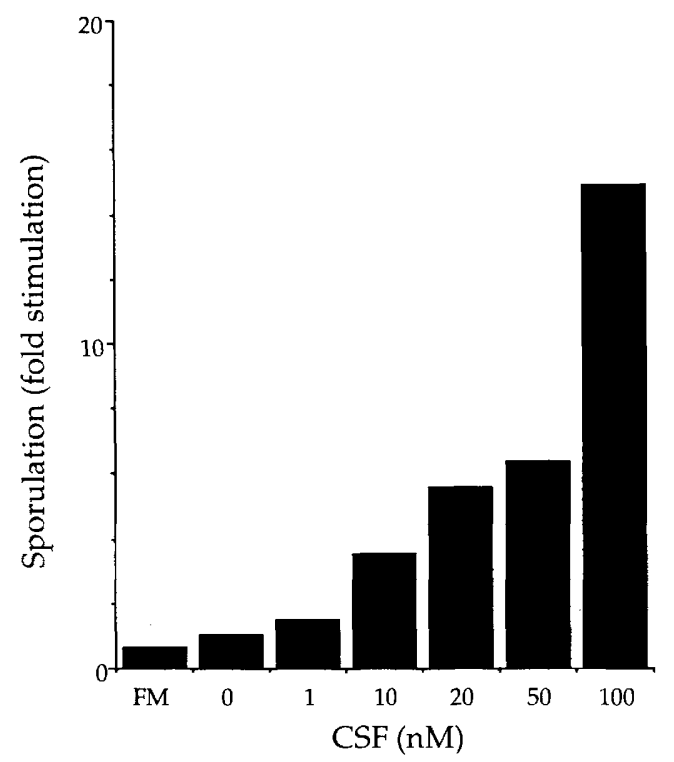

Figure 6. CSF stimulates sporulation of nutrient-deprived cells at low cell density. Strain AG130 (wild type) was grown in minimal medium and diluted to low density $\left(\mathrm{OD}_{600} \sim 0.03\right)$ in fresh medium (FM) or conditioned medium from a spoOA null mutant (JMS700) with the indicated concentration of the chemically synthesized ERGMT peptide. Decoyinine $(500 \mu \mathrm{g} / \mathrm{ml})$ was added to initiate starvation conditions and viable cells and spores were measured 12-14 hr after the addition of decoyinine. The fold stimulation of sporulation is the percent sporulation under the indicated condition divided by the percent sporulation of cells at low density in untreated medium (fresh medium). Sporulation at high cell density was $-26 \%$; sporulation at low cell density was $\sim 0.1 \%$. detected it in our assays. The rapC null mutation also had no obvious effect on sporulation (data not shown). A much more detailed analysis will be necessary to detect possible effects of the $p h r C$ and rapC mutations on sporulation.

\section{Discussion}

We have purified and characterized a competence and sporulation stimulating factor, CSF, that accumulates as cells grow to high density. CSF is the carboxy-terminal 5 amino acids (ERGMT) of a 40-amino-acid peptide encoded by, phrC (Carter et al. 1991; Perego et al. 1996), an open reading frame downstream from a promoter controlled by the $s p o O H$ gene product, sigma-H. No detectable CSF is produced in a phrC deletion mutant, causing a delay in the induction of competence gene expression.

Under the conditions tested, CSF is an auxiliary competence pheromone, it modulates the timing and absolute levels of competence development. The major extracellular competence factor is the ComX pheromone, which is responsible for the bulk of the extracellular competence-inducing activity produced by growing cells. It is not clear why $B$. subtilis has two competence pheromones, but their relative abundance could vary under different growth conditions to control the timing of competence development.

A relatively simple model (Fig. 7) explains the stimulatory effects of both competence pheromones on expression of srfA. The ComX pheromone probably interacts directly with the ComP histidine protein kinase, stimulating autophosphorylation by ComP and transfer of phosphate to ComA (Solomon et al. 1995). CSF is transported into the cell by the oligopeptide permease encoded by spoOK, a member of the ATP-binding-cassette family of transporters (Higgins 1992) that is required for both competence development and sporulation (Perego et al. 1991; Rudner et al. 1991). CSF then affects competence by acting (directly or indirectly) as a negative regulator of the activity or expression of the phosphatase encoded by $\operatorname{rap} C$, the gene immediately upstream of phrC. The RapC phosphatase is required for CSF to stimulate expression of $\operatorname{srf} A$ (Fig. $2 \mathrm{~B})$ and RapC is a negative regulator of $s r f A$ expression (Fig. $4 \mathrm{~A}$ ), most likely by inhibiting accumulation of the phosphorylated form of the ComA transcription factor, the direct activator of $\operatorname{srf} A$ expression. In this way, the two extracellular competence factors control opposing processes; ComX pheromone stimulates a kinase, whereas CSF inhibits a phosphatase. It is not surprising that the factor (ComX pheromonel that regulates the kinase is the major competence pheromone, whereas CSF, which regulates the phosphatase, has a modulating effect.

Whereas the SpoOK oligopeptide permease regulates induction of srfA in response to CSF (Solomon et al. 1995), the permease must also affect $\operatorname{srf} A$ expression in other ways. Expression of $s r f A$ is severely reduced (to $\sim 5 \%$ of wild type) in a spoOK null mutant (Magnuson et al. 1994; Solomon et al. 1995). In contrast, a phrC (CSF) null mutation causes only a modest reduction in $\operatorname{sr} A$ 


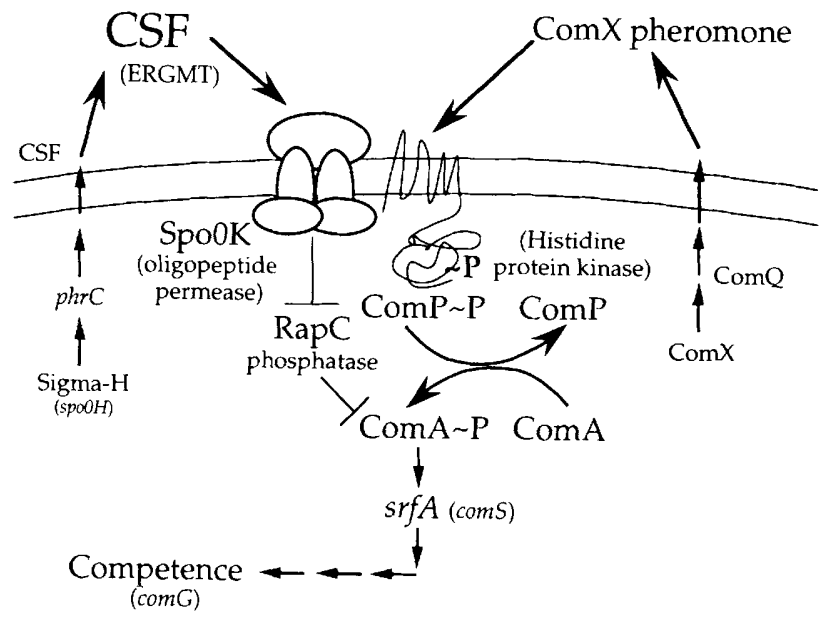

Figure 7. Model for cell density regulation of $\operatorname{srf} A$ expression and competence in B. subtilis. Two extracellular factors, ComX pheromone and CSF / competence and sporulation stimulating factor) stimulate expression of $s r f A$ (comS). CSF is the 5-aminoacid peptide ERGMT and is encoded by phrC. Transcription of phrC is controlled, in part, by the sigma factor of RNA polymerase, sigma-H, encoded by spoOH. Response to CSF requires the oligopeptide permease encoded by $S p o O K$ and the phosphatase encoded by RapC. CSF is probably transported into the cell by the oligopeptide permease and inhibits activity of the RapC phosphatase (either directly or indirectly). The ComX pheromone is a 9- or 10-amino-acid peptide with a hydrophobic modification in place of a tryptophan residue, and ComQ is required for production of the active pheromone (Magnuson et al. 1994). Response to the ComX pheromone requires the membrane-bound histidine protein kinase encoded by comP. ComA is the transcription factor that directly activates expression of $\operatorname{srf} A$, and phosphorylation (activation) of ComA is controlled by ComP (kinase) and RapC (phosphatase).

expression (Fig. 4). Since the oligopeptide permease is probably involved in regulating multiple phosphatases (and perhaps kinases), the severe defect in $\operatorname{srf} A$ expression in the spoOK null mutant might reflect hyperactivity of several other phosphatases (see below), leading to decreased expression of $\operatorname{srf} A$. In addition, if the only role of the oligopeptide permease in competence was to transport CSF to inhibit the RapC phosphatase, then the competence defect caused by a spoOK null mutation should be suppressed by a rapC null mutation. This is not the case (data not shown). Together, these results indicate that $\mathrm{SpoOK}$ is affecting srfA expression by at least one pathway other than that involving CSF and RapC.

Whereas relatively low concentrations $(2-5 \mathrm{nM})$ of CSF stimulate expression of $\operatorname{sr} A$, high concentrations 150 $100 \mathrm{~nm}$ ) actually inhibit expression. This inhibition does not depend on the RapC phosphatase, indicating that CSF is affecting at least one other regulatory factor. Candidate targets for this inhibition could be other phosphatases that might indirectly cause inhibition of $s r f A$ expression. The levels of CSF that inhibit expression of $\operatorname{srf} A$ stimulate the sporulation pathway. Because activa- tion of the early regulatory steps in sporulation can inhibit competence (for review, see Grossman 1995), the inhibition of srfA at higher levels of CSF might be attributable to activation of the sporulation pathway.

In addition to the two extracellular peptide factors that affect competence (Fig. 7), there are also multiple extracellular peptide factors that affect sporulation. We have shown that one of the sporulation factors is CSF. The initial indication that sporulation was influenced by peptide factors came from experiments done with cells subjected to starvation conditions at low cell density. Under these conditions, sporulation is inefficient (Vasantha and Freese 1979; Grossman and Losick 1988; Waldburger et al. 1993). Conditioned medium from cells grown to high density contains at least two different peptide factors that contribute to this cell density effect (J.M. Soloman and A.D. Grossman, unpubl.) and one of these factors copurified with CSF. The identification of CSF allowed us to test its role in sporulation using the chemically synthesized peptide. CSF is able to enhance sporulation of nutrient-deprived cells at low cell density, but the amount that is needed (50-100 nM) is much greater than the amount needed (1-10 nM) to stimulate expression of srfA. Based on these results, we propose that CSF contributes to a regulatory switch that initially favors competence and then favors sporulation and inhibits competence. This is consistent with the fact that competence can develop during exponential growth (Dubnau et al. 1991; Magnuson et al. 1994; Grossman 1995), whereas the initiation of sporulation is post-exponential (Errington 1993; Hoch 1993; Grossman 1995).

The cell density effect on sporulation affects activation of the Spo0A transcription factor (Ireton et al. 1993). Constitutively active forms of Spo0A completely bypass the need for high cell density, allowing efficient sporulation of cells at low density (Ireton et al. 1993). This indicates that the cell density factors needed for sporulation stimulate production of the phosphorylated form of Spo0A (directly or indirectly). Spo0A normally obtains phosphate from a combination of three histidine protein kinases (Perego et al. 1989; Antoniewski et al. 1990; Trach and Hoch 1993; Kobayashi et al. 1995; LeDeaux and Grossman 1995; LeDeaux et al. 1995) and a multicomponent phosphorelay (Burbulys et al. 1991; Hoch 1993). The amount of Spo0A $\sim \mathrm{P}$ that accumulates is controlled, in part, by the activity of the kinases, and by the opposing activities of phosphatases (see below). Whereas we have not identified the genes necessary for CSF to stimulate sporulation, we suspect that CSF might be inhibiting phosphatases on the sporulation pathway, perhaps RapA and RapB (see below). In addition, we suspect that some of the extracellular sporulation factors are stimulating at least one of the sporulation kinases, perhaps analogous to the role of ComX pheromone in stimulating the ComP histidine protein kinase (Fig. 7).

Several genes have been identified in $B$. subtilis that encode products that are homologous to RapA, a response regulator aspartyl phosphate phosphatase (Mueller and Sonenshein 1992; Mueller et al. 1992; Perego et al. 1994, 1996). Whereas our results show that RapC is a 
negative regulator of competence, both RapA and RapB were found to be negative regulators of sporulation (Mueller and Sonenshein 1992; Mueller et al. 1992; Perego et al. 1994). RapA has been purified and shown to be a phosphatase for SpoOF P (Perego et al. 1994), an intermediate in the phosphorelay pathway that controls the initiation of sporulation (Burbulys et al. 1991; Hoch 1993). Null mutations in $\operatorname{rapA}$ (gsiA) cause enhanced sporulation (Mueller and Sonenshein 1992; Mueller et al. 1992; Perego et al. 1994) by allowing more efficient activation of Spo0A.

Many of the genes encoding response regulator aspartyl phosphate phosphatases are followed by small open reading frames that could encode extracellular peptides (Perego et al. 1996). phrA, downstream of $\operatorname{rapA}$, is required for the initiation of sporulation (Perego and Hoch 1996) and this requirement is bypassed by a null mutation in rapA (Perego and Hoch 1996), indicating that a phrA product is positively regulating phosphorylation of Spo0A. A phrA mutant can also be rescued extracellularly, either by mixing with other cells or by addition of various peptides corresponding the carboxy-terminal region of the $p h r A$ gene product, indicating that a product of $p h r A$ probably accumulates extracellularly to regulate sporulation (Perego and Hoch 1996). It is not clear if the phrA factor contributes to the cell density effect on sporulation, but phrA mutants still make at least two additional sporulation factors found in culture supernatant (J.M. Solomon and A.D. Grossman, unpubl.).

The SpoOK oligopeptide permease is clearly able to transport CSF (see Results) and is almost certainly involved in transporting other peptide signaling factors. The requirement for the oligopeptide permease in sporulation is bypassed by a $\operatorname{rap} A \operatorname{rap} B$ double mutation (Perego and Hoch 1996), or by overexpressing either kinA (Rudner et al. 1991) or kinC (LeDeaux and Grossman 1995), histidine protein kinsaes that donate phosphate to Spo0F, leading to activation of SpoOA. Together, these results imply two possible roles for peptides transported by the oligopeptide permease; to inhibit phosphatases, and/or to stimulate histidine protein kinases.

There appears to be a cell-cell signaling pathway for the initiation of sporulation that is independent of the oligopeptide permease and RapC. rapC null mutations have no obvious effect on sporulation (data not shown) and, like wild-type cells, sporulate more poorly at low cell density. spoOK mutants have a decreased frequency of sporulation, but that frequency is still reduced further at low cell density (J.M. Solomon, B.A. Lazazzera, R. Magnuson, J. LeDeaux, K. Ireton, and A.D. Grossman, unpubl.). These results indicate that there is a cell-cell signaling pathway controlling the initiation of sporulation that is independent of RapC and SpoOK. We suspect that this pathway involves one or another of the histidine protein kinases that contribute to the initiation of sporulation (for review, see Grossman 1995).

It is apparent that $B$. subtilis, like many species of microbes, goes to great lengths to monitor its local concentration and modify gene expression and development in response to cell density signals. The multiplicity of phr genes indicates that many different processes in $B$. subtilis may be controlled by cell density factors or quorum sensing. Alternatively, the different peptides may be expressed under different conditions and might contribute to regulation of a limited number of regulatory responses (e.g., competence and sporulation). If these products are actually affecting gene expression, it seems fitting to call the phr products pheromones ("chemicals produced by an organism that can alter behavior or gene expression of other organisms of the same species") (Lodish et al. 1995!.

\section{Materials and methods}

Strains and lacZ fusions

B. subtilis strains used are listed in Table 1 and unless indicated otherwise are derived from parent strain JH642 and contain trpC and pheA mutations. The srfA-lacZ $\Omega 1974$ fusion is a translational fusion located in single copy at the amyE locus and was provided by J. Hahn and D. Dubnau (Hahn et al. 1994). It was used in most of the experiments involving the purification of CSF and had been used previously in the characterization of the ComX pheromone (Magnuson et al. 1994). The com G-lacZ fusion is a transcriptional fusion located at $a m y E$ (Magnuson et al. 1994).

Table 1. B. subtilis strains used

\begin{tabular}{|c|c|c|}
\hline Strain & Relevant genotype & Reference \\
\hline JRL293 & amy::(srfA-lacZ $\Omega 1974$ cat $)$ & Magnuson et al. 1994 \\
\hline JRL476 & amy::(srfA-lac $\Omega 1974$ cat::spc) & Magnuson et al. 1994 \\
\hline $\begin{array}{l}\text { AG1046 } \\
\text { (JMS107) }\end{array}$ & amyE::(comG-lacZ neo) & $\begin{array}{l}\text { Magnuson et al. 1994; } \\
\text { Siranosian and Grossman } 1994\end{array}$ \\
\hline AG130 & $\mathrm{SP} \beta:(\operatorname{spoVG-lacZ}$ erm cat $)$ trp ${ }^{+}$phe $^{+}$ & Grossman and Losick 1988 \\
\hline BAL116 & rapC::pJS49 (cat) amy::(srfA-lacZR1974 cat::spc) & \\
\hline BAL114 & rapC::pIS49 amyE::(com G-lacZ neo) & \\
\hline JMS700 & $\Delta$ spoOA::cat pheA trp ${ }^{+} \mathrm{SP}^{0}$ & \\
\hline JMS752 & $\Delta p h r C:: e r m$ amyE ::(com G-lacZ neo) & \\
\hline JMS753 & $\Delta p h r \mathrm{C}:: e r m$ amy::(srfA-lacZ $\Omega 1974$ cat::spc) & \\
\hline JMS761 & $\Delta c o m Q:: s p c$ amy::(srfA-lacZ 21974 cat $)$ & \\
\hline JMS762 & $\Delta c o m Q:: s p c \Delta p h r C:: e r m$ amy::(srfA-lacZ $\Omega 1974$ cat $)$ & \\
\hline
\end{tabular}




\section{Construction of phrC and rapC mutants.}

The phrC deletion was made by cloning regions upstream and downstream of the phrC open reading frame on either side of the erythromycin resistance gene (erm) and recombining this construct into the chromosome by double crossover. The deletion extends from codon 6 of $\mathrm{phrC}$ to $22 \mathrm{bp}$ downstream of the stop codon of $p h r C$, and removes the last five codons that encode CSF. The deletion-insertion mutation leaves intact the 3 ' end of rapC, which overlaps the 5' end of $p h r C$.

pIS48 contains the $\Delta p h r C:: e r m$ mutation. The regions upstream and downstream of $p h r C$ were cloned by PCR amplification using Vent polymerase and primers with restriction sites added at the end (underlined) to aid in the sub-cloning. The region upstream of $p h r C$ region was amplified with primers rapCl: 5'-AAGGATCCTACGTGGAGCAGGAAAC3' and rapC2: 5'-GGAATTCTGCGGCCAAACAAATAAC-3'. This fragment extends from 618 bp upstream of the phrC start codon to $24 \mathrm{bp}$ into the structural gene and was sub-cloned between the BamHI and EcoRI restriction sites of pJPM 8 (from J. Mueller and A.L. Sonenshein, Tufts University School of Medicine, Boston, MA) making plasmid pIS47. The region downstream of $p h r C$ was amplified using primers phrCl: $5^{\prime}$ ATAATGTCGACCGAGAAGGGGTTTTTC-3' and phrC2: $5^{\prime}$ AGGGCCCCTCTTGTCCACTATTATC-3'. This fragment extends from 22 bp downstream from the $p h r C$ stop codon to 461 bp downstream of the stop codon and was sub-cloned into the Sall and ApaI sites of pJS47 to make pJS48. pIS48 was linearized and transformed into wild-type $B$. subtilis selecting for $M L S^{R}$ transformants. The transformants were screened by PCR to confirm that a double crossover event had occurred (data not shown).

The rapC mutant was made by integrating a plasmid containing an internal fragment of $r a p C$ into the chromosome. The internal fragment was derived from the 1216-bp fragment that had been isolated following PCR amplification of the region between primers rapCl and phrC2 (described above). The PCR product was digested with $\mathrm{BamHI}$ and HindIII yielding a 327-bp piece that was subcloned into the BamHI and HindIII sites of pJH101 (Ferrari et al. 1983) to make pIS49. The internal fragment stops 101 codons from the end of rapC. pIS49 was integrated into the $B$. subtilis chromosome by transformation into wild-type cells selecting for resistance to chloramphenicol.

\section{Media}

Defined minimal medium was used for most experiments and contained S7 salts (Vasantha and Freese 1980) except that MOPS buffer was used at 50 rather than $100 \mathrm{~mm}$ (Jaacks et al. 1989). Medium contained glucose $(1 \%)$ and glutamate $(0.1 \%)$ and required amino acids $(40$ or $50 \mu \mathrm{g} / \mathrm{ml}$ ) as needed.

\section{$\beta$-galactosidase assays}

$\beta$-galactosidase specific activity was measured essentially as described (Miller 1972; Jaacks et al. 1989; Magnuson et al. 1994) and is presented as $\left(\Delta \mathrm{A}_{420}\right.$ per min per $\mathrm{ml}$ of culture per $\left.\mathrm{OD}_{600}\right) \times 1000$.

\section{Spore assays and the effect of CSF on sporulation}

Sporulation frequencies were determined as the number of heat resistant $\left(80^{\circ} \mathrm{C}\right.$ for $20 \mathrm{~min}$ ) colony forming units as a fraction of total colony forming units on LB plates. Strain AG130 was grown to an $\mathrm{OD}_{600}$ of $0.3-0.5$ in defined minimal medium for at least 3 generations. Cells were diluted to low density (typically a 10-fold and/or a 50-fold dilution) in fresh medium, conditioned medium from a spoOA mutant, or conditioned medium from a $S P O 0 A$ mutant with CSF peptide added at indicated concentrations. Conditioned medium from JMS700 (spo0A) was made from cells grown to late exponential phase in defined minimal medium. Nutrient deprivation conditions were imposed by the addition of decoyinine (U-7984; Upjohn Co.), an inhibitor of GMP synthetase, to a concentration of $500 \mu \mathrm{g} / \mathrm{ml}$, essentially as described previously (Mitani et al. 1977; Grossman and Losick 1988). The numbers of viable cells and heat resistant spores were determined $12-14 \mathrm{hr}$ after addition of decoyinine.

\section{Purification of CSF}

CSF was purified from conditioned medium made from strain ROM186 (prototroph, $\Delta$ spo0K357::neo spoIVC::Tn917). The spoIVC mutation was used to completely block spore formation. The $s p o O K$ allele is a deletion insertion (LeDeaux and Grossman 1995) and was used because preliminary results indicated that $5 P O O K$ null mutations caused increased production of CSF, especially after entry into stationary phase (Solomon et al. 1995). The cells were grown essentially as described previously (Magnuson et al. 1994). Approximately $2 \mathrm{hr}$ after the onset of stationary phase, cells were removed by centrifugation and the supernatant was filter sterilized to produce cell-free conditioned medium.

One liter of conditioned medium was adjusted to $\mathrm{pH} 2$ with trifluoroacetic acid (TFA), and run by gravity over $\mathrm{C} 18$ reverse phase column (Preparative Cl 8 125à, Waters). $250 \mathrm{ml}$ portions of conditioned medium were applied to $100 \mathrm{~g}$ of column matrix. The column was washed with buffer containing $0.1 \%$ TFA and CSF was eluted with $11 \%$ acetonitrile in the same buffer. These $11 \%$ acetonitrile fractions were concentrated by speed-vac, resuspended in $50 \mathrm{~mm}$ citrate buffer $(\mathrm{pH} 3)$, and adsorbed to a 100 ml Source $30 S$ cation exchange FPLC column (Pharmacia). After washing the column with $50 \mathrm{~mm}$ citrate buffer containing 25 $\mathrm{mM} \mathrm{NaCl}$, CSF was eluted with $500 \mathrm{mM} \mathrm{NaCl}$. The buffers and salts were removed from the active fractions by reverse phase chromatography as described for the treatment of crude conditioned medium, except that $10 \mathrm{~g} \mathrm{C} 18$ reverse phase columns (Waters) were used.

All subsequent purification steps used high pressure liquid chromatography (HPLC). The material was first run on a sulfoethylaspartamide column (The Nest Group). The loading buffer was $5 \mathrm{mM} \mathrm{KH}_{2} \mathrm{PO}_{4}, 25 \%$ acetonitrile, $\mathrm{pH} \mathrm{3}$, and the material was eluted with a $12.5 \mathrm{~mm} /$ minute gradient of $\mathrm{NaCl}$. Active fractions were then subjected to three reverse phase chromatography steps. The first was a Xorbax $\mathrm{C} 18$ column, $4.6 \mathrm{~mm}$ (DuPont). Material was adsorbed in $1.6 \%$ acetonitrile, $0.1 \%$ TFA and eluted in a very shallow gradient $10.05 \%$ acetonitrile/ minute). Active fractions were again run on the Xorbax $\mathrm{C} 18$ column substituting $5 \mathrm{~mm}$ hydrochloric acid for $0.1 \%$ TFA. The CSF activity was eluted with an isocratic wash of $5 \mathrm{~mm} \mathrm{HCl}$. The final reverse phase step used a $1 \mathrm{~mm}$ Vydac C18 column (The Nest Group). The material was loaded in buffer containing $1.6 \%$ acetonitrile, $0.1 \%$ TFA, and CSF was eluted with a $10 \mathrm{~min}$ isocratic wash followed by a gradient of $0.1 \%$ acetonitrile/ minute.

After each step in the purification, active fractions were concentrated by speed-vac as necessary. Concentrated fractions were resuspended in buffers appropriate for the next step in the purification and the $\mathrm{pH}$ was adjusted as necessary.

\section{Assay of CSF activity}

CSF activity was measured essentially as described previously 
(Solomon et al. 1995). Cells containing the srfA-lacZ $21974 \mathrm{fu}-$ sion (JRL293 or JRL476) were grown for at least three doublings to an optical density of approximately $0.05-0.1$ at $600 \mathrm{~nm} .0 .25$ $\mathrm{ml}$ of cells were mixed with $0.25 \mathrm{ml}$ of the sample to be assayed, with $50 \mu \mathrm{g} / \mathrm{ml} \mathrm{BSA}$ to prevent nonspecific loss of activity (Magnuson et al. 1994), incubated at $37^{\circ} \mathrm{C}$ for $70 \mathrm{~min}$, and assayed for $\beta$-galactosidase-specific activity. The response to CSF was linear only over a small concentration range and assays were typically done on a series of two-fold dilutions. Dilutions in the linear range were used to calculate the units of CSF per milliliter of conditioned medium. One unit of CSF activity is defined as the amount needed to induce expression of the $\operatorname{srf} A$ lacZ $\Omega 1974$ fusion in strain JRL293 (or JRL476) to an activity of one $\beta$-galactosidase-specific activity unit above the background of untreated cells (fresh medium) in $70 \mathrm{~min}$.

\section{Analysis and synthesis of CSF}

Peptide sequencing was done by the MIT Biopolymers Lab, in the Department of Biology, MIT and by the Microchemistry Lab, Harvard University. Synthesis of ERGMT was done by Genemed Biotechnologies, S. San Francisco, CA. MALDI/TOF mass spectrometry was done on a Voyager Elite machine (PerSeptive Biosystems) both in the lab of Paul Matsudaira, Whitehead Institute, Department of Biology, MIT and in the lab of Klaus Biemann by Susan Wolf in the Department of Chemistry, MIT.

\section{Acknowledgments}

We are grateful to P. Matsudaira and T. Baker for advice and use of HPLC equipment; P. Matsudaira for use of his mass spectrometer; R. Cook, W. Lane for peptide sequencing; and P. Matsudaira, Susan Wolf, and K. Biemann for mass spectrophotometric analysis. R. Magnuson first noticed the unusual dose response properties of partly purified CSF. We are grateful to members of our lab for useful discussions, comments, and suggestions on the manuscript. We thank C. Price, D. Dubnau, and S. Bell for comments on the manuscript; M. Nakano and P. Zuber for communication of results prior to publication.

J.M.S. was supported by a Howard Hughes predoctoral fellowship. A.D.G. was a Lucille P. Markey Scholar in Biomedical Sciences and this work was supported in part by a grant from the Lucille P. Markey Charitable Trust, and Public Health Services grants GM41934 and GM50895 to A.D.G. from the National Institutes of Health.

The publication costs of this article were defrayed in part by payment of page charges. This article must therefore be hereby marked "advertisement" in accordance with 18 USC section 1734 solely to indicate this fact.

\section{References}

Antoniewski, C., B. Savelli, and P. Stragier. 1990. The spoII gene, which regulates early developmental steps in Bacillus subtilis, belongs to a class of environmentally responsive genes. J. Bacteriol. 172: 86-93.

Burbulys, D., K.A. Trach, and J.A. Hoch. 1991. Initiation of sporulation in $B$. subtilis is controlled by a multicomponent phosphorelay. Cell 64: 545-552.

Carter, H.L., III, K.M. Tatti, and C.P. Moran, Jr. 1991. Cloning of a promoter used by sigma-H RNA polymerase in Bacillus subtilis. Gene 96: 101-105.

D'Souza, C., M.M. Nakano, and P. Zuber. 1994. Identification of com $S$, a gene of the $s r f A$ operon that regulates the establish- ment of genetic competence in Bacillus subtilis. Proc. Natl. Acad. Sci. 91: 9397-9401.

Dubnau, D. 1991. Genetic competence in Bacillus subtilis. Microbiol. Rev. 55: 395-424.

Dubnau, D., J. Hahn, L. Kong, M. Roggiani, and Y. Weinrauch. 1991. Genetic competence as a post-exponential global response. Seminars in Dev. Biol. 2: 3-11.

Errington, J. 1993. Bacillus subtilis sporulation: Regulation of gene expression and control of morphogenesis. Microbiol. Rev. 57: 1-33.

Ferrari, F.A., A. Nguyen, D. Lang, and J.A. Hoch. 1983. Construction and properties of an integrable plasmid for Bacillus subtilis. J. Bacteriol. 154: 1513-1515.

Fuqua, W.C., S.C. Winans, and E.P. Greenberg. 1994. Quorum sensing in bacteria: The LuxR-LuxI family of cell densityresponsive transcriptional regulators. I. Bacteriol. 176: 269275.

Grossman, A.D. 1995. Genetic networks controlling the initiation of sporulation and the development of genetic competence in Bacillus subtilis. Annu. Rev. Genet. 29: 477-508.

Grossman, A.D. and R. Losick. 1988. Extracellular control of spore formation in Bacillus subtilis. Proc. Natl. Acad. Sci. 85: 4369-4373.

Hahn, J. and D. Dubnau. 1991. Growth stage signal transduction and the requirements for $s r f A$ induction in development of competence. J. Bacteriol. 173: 7275-7282.

Hahn, J., L. Kong, and D. Dubnau. 1994. The regulation of competence transcription factor synthesis constitutes a critical control point in the regulation of competence in Bacillus subtilis. J. Bacteriol. 176: 5753-5761.

Hamoen, L.W., H. Eshuis, I. Jongbloed, G. Venema, and D. van Sinderen. 1995. A small gene, designated coms, located within the coding region of the fourth amino acid-activation domain of $\operatorname{srf} A$, is required for competence development in Bacillus subtilis. Mol. Microbiol. 15: 55-63.

Higgins, C.F. 1992. ABC transporters: From microorganisms to man. Annu. Rev. Cell Biol. 8: 67-113.

Hoch, J.A. 1993. Regulation of the phosphorelay and the initiation of sporulation in Bacillus subtilis. Annu. Rev. Microbiol. 47: 441-465.

Ireton, K., D.Z. Rudner, K.J. Siranosian, and A.D. Grossman. 1993. Integration of multiple developmental signals in $\mathrm{Ba}$ cillus subtilis through the Spo0A transcription factor. Genes \& Dev. 7: 283-294.

Jaacks, K.J., J. Healy, R. Losick, and A.D. Grossman. 1989. Identification and characterization of genes controlled by the sporulation regulatory gene spoOH in Bacillus subtilis. I. Bacteriol. 171: 4121-4129.

Kaiser, D. and R. Losick. 1993. How and why bacteria talk to each other. Cell 73: 873-885.

Kobayashi, K., K. Shoji, T. Shimizu, K. Nakano, T. Sato, and Y. Kobayashi. 1995. Analysis of a suppressor mutation $s s b$ (kinC) of surOB20 (spoOA) mutation in Bacillus subtilis reveals that $\operatorname{kin} C$ encodes a histidine protein kinase. J. Bacteriol. 177: 176-182.

LeDeaux, J.R. and A.D. Grossman. 1995. Isolation and characterization of $\operatorname{kin} C$, a gene that encodes a sensor kinase homologous to the sporulation sensor kinases KinA and KinB in Bacillus subtilis. J. Bacteriol. 177: 166-175.

LeDeaux, J.R., N. Yu, and A.D. Grossman. 1995. Different roles for KinA, KinB, and KinC in the initiation of sporulation in Bacillus subtilis. J. Bacteriol. 177: 861-863.

Lodish, H., D. Baltimore, A. Berk, S.L. Zipursky, P. Matsudaira, and J. Darnell. 1995. Molecular Cell Biology, 3rd ed. W.H. Freeman \& Co., New York.

Magnuson, R., J. Solomon, and A.D. Grossman. 1994. Biochem- 
ical and genetic characterization of a competence pheromone from B. subtilis. Cell 77: 207-216.

Miller, J. 1972. Experiments in molecular genetics. Cold Spring Harbor Laboratory, Cold Spring Harbor, New York.

Mitani, T., J.F. Heinze, and E. Freese. 1977. Induction of sporulation in Bacillus subtilis by decoyinine or hadacidin. Biochem. Biophys. Res. Commun. 77: 1118-1125.

Mueller, J.P. and A.L. Sonenshein. 1992. Role of the Bacillus subtilis gsiA gene in regulation of early sporulation gene expression. I. Bacteriol. 174: 4374-4383.

Mueller, J.P., G. Bukusoglu, and A.L. Sonenshein. 1992. Transcriptional regulation of Bacillus subtilis glucose starvationinducible genes: Control of $g s i A$ by the ComP-ComA signal transduction system. /. Bacteriol. 174: 4361-4373.

Nakano, M.M. and P. Zuber. 1989. Cloning and characterization of $\operatorname{srf} B$, a regulatory gene involved in surfactin production and competence in Bacillus subtilis. /. Bacteriol. 171: $5347-5353$.

-1991. The primary role of ComA in establishment of the competent state in Bacillus subtilis is to activate expression of srfA. I. Bacteriol. 173: 7269-7274.

Nakano, M.M., R. Magnuson, A. Meyers, J. Curry, A.D. Grossman, and P. Zuber. 1991a. srfA is an operon required for surfactin production, competence development, and efficient sporulation in Bacillus subtilis. I. Bacteriol. 173: 1770-1778.

Nakano, M.M., L. Xia, and P. Zuber. 1991b. Transcription initiation region of the srfA operon, which is controlled by the ComP-ComA signal transduction system in Bacillus subtilis. J. Bacteriol. 173: 5487-5493.

Perego, M. and J.A. Hoch. 1996. Cell-cell communication regulates the effects of protein aspartate phosphatases on the phosphorelay controlling development in Bacillus subtilis. Proc. Natl. Acad. Sci. 93: 1549-1553.

Perego, M., S.P. Cole, D. Burbulys, K. Trach, and J.A. Hoch. 1989. Characterization of the gene for a protein kinase which phosphorylates the sporulation-regulatory proteins SpoOA and SpoOF of Bacillus subtilis. I. Bacteriol. 171: 6187-6196.

Perego, M., C.F. Higgins, S.R. Pearce, M.P. Gallagher, and J.A. Hoch. 1991. The oligopeptide transport system of Bacillus subtilis plays a role in the initiation of sporulation. Mol. Microbiol. 5: 173-185.

Perego, M., C. Hanstein, K.M. Welsh, T. Djavakhishvili, P. Glasser, and J.A. Hoch. 1994. Multiple protein-aspartate phosphatases provide a mechanism for the integration of diverse signals in the control of development in $B$. subtilis. Cell 79: 1047-1055.

Perego, M., P. Glaser, and J.A. Hoch. 1996. Aspartyl-phosphate phosphatases deactivate the response regulator components of the sporulation signal transduction system in Bacillus subtilis. Mol. Microbiol. 19: 1151-1157.

Roggiani, M. and D. Dubnau. 1993. ComA, a phosphorylated response regulator protein of Bacillus subtilis, binds to the promoter region of srfA. J. Bacteriol. 175: 3182-3187.

Rudner, D.Z., J.R. LeDeaux, K. Ireton, and A.D. Grossman. 1991. The spoOK locus of Bacillus subtilis is homologous to the oligopeptide permease locus and is required for sporulation and competence. J. Bacteriol. 173: 1388-1398.

Siranosian, K.J. and A.D. Grossman. 1994. Activation of spoOA transcription by sigma-H is necessary for sporulation but not for competence in Bacillus subtilis. J. Bacteriol. 176: 3812 3815.

Solomon, J.M. and A.D. Grossman. 1996. Who's competent and when: Regulation of natural genetic competence in bacteria. Trends Genet. 12: 150-155.

Solomon, J.M., R. Magnuson, A. Srivastava, and A.D. Gross- man. 1995. Convergent sensing pathways mediate response to two extracellular competence factors in Bacillus subtilis. Genes \& Dev. 9: 547-558.

Spizizen, J. 1958. Transformation of biochemically deficient strains of Bacillus subtilis by deoxyribonucleate. Proc. Nat. Acad. Sci. 44: 1072-1078.

Trach, K.A. and J.A. Hoch. 1993. Multisensory activation of the phosphorelay initiating sporulation in Bacillus subtilis: Identification and sequence of the protein kinase of the alternate pathway. Mol. Microbiol. 8: 69-79.

van Sinderen, D. and G. Venema. 1994. comK acts as an autoregulatory control switch in the signal transduction route to competence in Bacillus subtilis. I. Bacteriol. 176: 57625770 .

van Sinderen, D., S. Withoff, H. Boels, and G. Venema. 1990. Isolation and characterization of $\operatorname{com} L$, a transcription unit involved in competence development of Bacillus subtilis. Mol. Gen. Genet. 224: 396-404.

van Sinderen, D., A. ten Berge, B.J. Hayema, L. Hamoen, and G. Venema. 1994. Molecular cloning and sequence of $c o m K$, a gene required for genetic competence in Bacillus subtilis. Mol. Microbiol. 11: 695-703.

van Sinderen, D., A. Luttinger, L. Kong, D. Dubnau, G. Venema, and L. Hamoen. 1995. comK encodes the competence transcription factor, the key regulatory protein for competence development in Bacillus subtilis. Mol. Microbiol. 15: 455462.

Vasantha, N. and E. Freese. 1979. The role of manganese in growth and sporulation of Bacillus subtilis. I. Gen. Microbiol. 112: 329-336.

- 1980. Enzyme changes during Bacillus subtilis sporulation caused by deprivation of guanine nucleotides. I. Bacteriol. 144: 1119-1125.

Waldburger, C., D. Gonzalez, and G.H. Chambliss. 1993. Characterization of a new sporulation factor in Bacillus subtilis. I. Bacteriol. 175: 6321-6327.

Weinrauch, Y., R. Penchev, E. Dubnau, I. Smith, and D. Dubnau. 1990. A Bacillus subtilis regulatory gene product for genetic competence and sporulation resembles sensor protein members of the bacterial two-component signal-transduction systems. Genes \& Dev. 4: 860-872. 


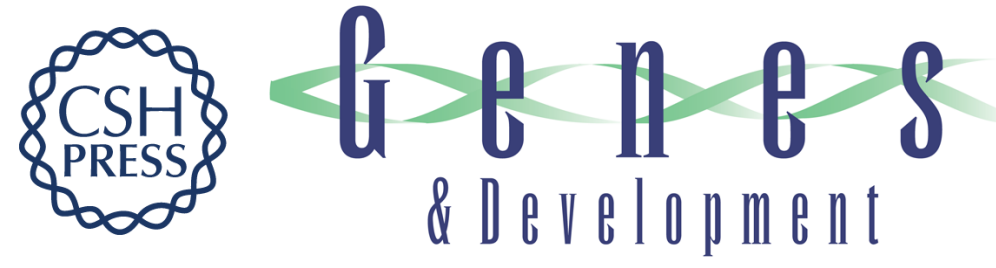

\section{Purification and characterization of an extracellular peptide factor that affects two different developmental pathways in Bacillus subtilis.}

J M Solomon, B A Lazazzera and A D Grossman

Genes Dev. 1996, 10:

Access the most recent version at doi:10.1101/gad.10.16.2014

References This article cites 50 articles, 31 of which can be accessed free at:

http://genesdev.cshlp.org/content/10/16/2014.full.html\#ref-list-1

License

Email Alerting

Service

Receive free email alerts when new articles cite this article - sign up in the box at the top right corner of the article or click here.

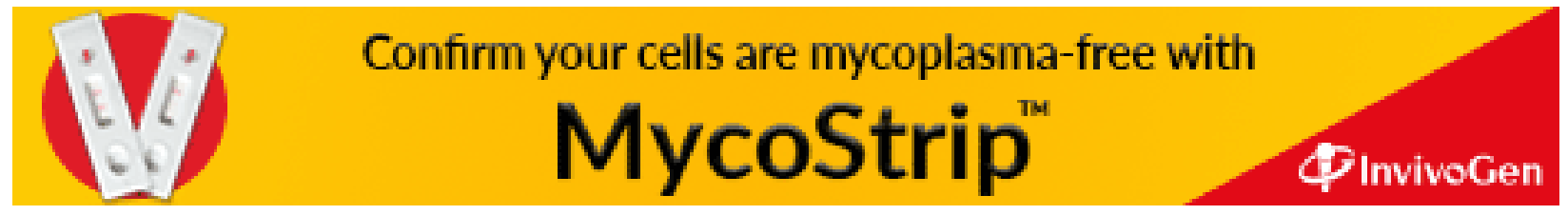

